\title{
PENINGKATAN KETERAMPILAN SOSIAL MELALUI KEGIATAN BERMAIN MENGGUNAKAN NYANYIAN
}

\author{
( Penelitian Tindakan di Kelompok B5 TK YPPK Bintang Kecil, Kecamatan
}

Abepura, Kota Jayapura, Provinsi Papua, 2014 )

\section{The Improvement Of Social Skills By Play Activities With The Song ( An Action Research In Group B5 TK YPPK Bintang Kecil, Kecamatan Abepura, Kota Jayapura 2014)}

\section{DIANA SETYANINGSIH}

\begin{abstract}
Abstrac : the aims of this reseacrh is to get information and data about the effort to increase children's social skills in group B5 kindergarten through play activities with the song in TK YPPK Bintang Kecil, Abepura, Jayapura City 2014, with 18 children. Reseacrh Method used action research method. This method condused in two ciycles according to kemmis and Taggart model which consist of 4 stages (plan, action, observation and reflection). The process of data collection using the interview notes, field notes, instrument monitoring and documentation of action. Analysis of data using qualitative analysis and quantitative analysis. Social skills children can be increased after the action through play activities using singing. It can be seen from the results of research that says that the average grade in the pre-action amounted to $49.30 \%$. After the action in the first cycle increases the average grade was increased to $71.18 \%$ and the second cycle increased to $84.42 \%$.
\end{abstract}

Keywords: Social Skills, Play With Songs, Action Research.

\begin{abstract}
Abstrak : Tujuan penelitian ini adalah untuk mendapatkan informasi dan data tentang upaya untuk meningkatkan keterampilan sosial anak kelompok B5 melalui kegiatan bermain menggunakan nyanyian di TK YPPK Bintang Kecil Abepura, Kota Jayapura, dengan jumlah anak sebanyak 18 orang. Metode yang digunakan adalah metode Kemmis dan Taggart yang terdiri dari perencanaan, tindakan, observasi, dan refleksi. Teknik pengumpulan data yang digunakan adalah observasi, wawancara, catatan lapangan, instrumen pemantau tindakan dan dokumentasi. Analisis data menggunakan analisis kualitatif dan analisis kuantitatif. Hasil data tersebut menunjukan bahwa keterampilan sosial anak dapat meningkat setelah dilakukan tindakan melalui kegiatan bermain menggunakan nyanyian. Hal ini dapat dilihat dari hasil penelitian yang menyebutkan bahwa rerata kelas pada pra tindakan sebesar $49,30 \%$. Setelah dilakukan tindakan dalam siklus I meningkat rerata kelas menjadi sebesar $71,18 \%$ dan siklus II meningkat menjadi $84,42 \%$.Dari hasil penelitian ini maka dapat disimpulkan bermain dengan menggunakan nyanyian dapat meningkatkan keterampilan sosial anak.
\end{abstract}

Kata kunci : Keterampilan Sosial, Bermain dengan Nyanyian, Penelitian Tindakan. 


\section{Pendahuluan}

Anak adalah anugerah terindah yang diberikan Tuhan yang Maha Kuasa, dimana anak dibekali dengan berbagai potensi yang dapat dikembangkan melalui pengasuhan dan pendidikan. Secara alamiah, perkembangan anak berbeda-beda, baik secara intelegensi, bakat, minat, kreativitas, kematangan emosi, kepribadian, kemandirian, jasmani dan rohani juga sosialnya. Pendidikan anak usia dini merupakan dasar dari pendidikan anak selanjutnya. Salah satu alasan dilakukannya pendidikan anak usia dini adalah untuk merangsang setiap aspek dan potensi perkembangan dan pertumbuhan anak dalam baik secara fisik dan phikis, dalam persiapannya memasuki kehidupan. Dewasa ini telah digalakkan program-program yang mendukung proses pembelajaran pada anak usia dini.

Taman kanak - kanak merupakan wadah bagi anak belajar seraya bermain, hal ini bertujuan memberi kesempatan bagi anak untuk bersosialisasi melalui kegiatan bermain. Di Taman kanak - kanak anak secara bertahap diperkenalkan, diajarkan, dan di tuntut untuk mengikuti berbagai keharusan yang kelak dapat menjadi bekal bagi anak dalam meneruskan jenjang pendidikannya. Salah satu kecakapan hidup yang harus dimiliki oleh anak yaitu keterampilan sosial. Dunia anak adalah bermain, karena melalui bermain anak belajar tentang banyak hal. Menurut Singer dalam Claudia Eliason mengatakan "Children need to begin to develop social values and skills in their earliest years, and this social learning should be active as they share different insights of people and culture". Pendapat ini menjelaskan bahwa sejak berusia dini dan telah memasuki masa pra sekolah, anak-anak perlu mengembangkan nilai-nilai sosial dan keterampilan sosialnya. Melalui pembelajaran sosial ini anak secara aktif dapat berbagi pengalaman kepada teman yang berbeda satu sama lain juga anak dapat menerima budaya teman lainnya.

Menurut Albert J. Cotugno (2009 : 46) mengatakan bahwa :"Social skills are the mechanisms 
through which individuals make contact, initiate, engage, and follow through in reciprocal social interchange. They are actual tools or skills needed for the socialization process to move forward and for meaningful relationships to be attempted and to succeed. For human beings, social competence provides the capacity to learn socialization skills, that is, the "legs" on which individuals can move forward, while social skills are the tool and techniques, the actual process of "learning to walk". Pendapat ini menjelaskan bahwa : keterampilan sosial adalah mekanisme saat dimana individu membuat kontak, memulai hubungan, terlibat, dan secara konsisten melakukan hubungan timbal balik dengan sesama. Oleh karena itu membina hubungan yang baik dengan orang lain merupakan keterampilan yang dibutuhkan untuk proses sosialisasi. Bagi kita kompetensi sosial menyediakan kapasitas untuk belajar tentang keterampilan sosial.
Dalam aspek perkembangan sosial, anak membutuhkan kondisi yang dapat membuat dirinya mampu memenuhi kebutuhan sosialnya. Kebutuhan sosial itu dapat dipenuhi melalui sosialisasi yaitu dengan menjalin hubungan dengan orang lain terutama dengan teman-teman sebayanya. Kebutuhan akan bergaul dan berinteraksi dengan banyak orang tidak lepas dari penciptaan manusia yang adalah memang sebagai mahkluk sosial.

Hasil obeservasi prapenelitian di TK YPPK Bintang Kecil Abepura ditemukan bahwa saat anak-anak bermain ada yang belum bisa menunggu giliran, saling berebutan dan kurang sabar, cenderung memilih teman, tidak mau bermain dengan lawan jenis, suka mengganggu teman dan pada akhirnya menimbulkan perkelahian . Berdasarkan gambaran tersebut, peranan guru sebagai fasilitator dan mediator benar-benar dituntut untuk lebih kreatif dan inovatif. Sekolah semestinya dapat menyiapkan media bermain yang memfasilitasi anak untuk bermain seraya belajar serta 
dapat mengembangkan seluruh potensi dan aspek yang dimilikinya terutama mengembangkan aspek keterampilan sosialnya. Permainan yang dimaksud dalam penelitian ini adalah permainan yang dilakukan secara bersamaan atau berkelompok dan dimainkan sambil mengikuti lagu atau nyanyian yang telah terlebih dahulu diajarkan. Dengan menambahkan nyanyian dalam setiap permainan, maka anak akan semakin tertarik untuk ikut serta dalam kegiatan bermain ini. Tujuan kegiatan bermain dengan menggunakan nyanyian ini adalah agar anak dapat mengembangkan interaksi sosial dengan teman sebaya dan menciptakan hubungan yang harmonis. Selain itu juga dengan menggunakan nyanyian dimaksudkan agar anak tidak cepat bosan, karena dengan ikut bernyanyi anak dapat belajar menyeimbangkan emosi serta mengembangkan sikap positif.

\section{Keterampilan Sosial}

Perkembangan keterampilan sosial anak sangat dipengaruhi oleh kondisi anak dan lingkungan sosialnya, baik orang tua, teman sebaya, dan masyarakat sekitar. Hal ini sejalan dengan pendapat Pamela May ( $2011: 24$ ) mengatakan bahwa : For young children to develop good social skills, or what is sometimes known as prosocial behavior, they need to feel good abaout themselves and to feel a certain amount of autonomy and independence. Hal ini menjelaskan bahwa anak-anak belajar mengembangkan keterampilan sosial dengan baik, saat mereka merasa nyaman dan merasa bebas mengeksplorasi perasaannya secara bebas. Melalui kebebasan dalam bergaul anak dengan mudah akan melakukan interaksi. Namun kebebasan tersebut tetap harus bertanggung jawab.

Menurut Lynch dan Simpson ( 2010 : 10 ) memaparkan bahwa social skills are behaviors that promote positive interactions withs others and the enviroment. Some of hese skills include showing empathy, participation in group activities, generosity, helpfullness, communicating with others, negotiating and problem solving. Hal 
ini menjelaskan bahwa keterampilan sosial dapat dikenalkan dan dikembangkan sejak usia dini meliputi, antara lain : bergaul dengan teman, saling berbagi dan menolong, bekerjasama, serta dapat memecahkan masalah, juga memahami aturan dan mengekpresikan perasaannya.

Nancy J. Patrick (2008 : 24) ikut menjelaskan bahwa : "Social skills are the capabilities that we are expected to use to interact with others in our society. They are based on the social norms of our society and they tell us what attitudes and behaviors are considered to be normal, acceptable and expected in a particular social situation”. Dari pengertian ini dapat disimpulkan bahwa keterampilan sosial ialah kemampuan dalam berinteraksi dengan orang lain. Pada anak usia dini diharapkan setelah mempelajari keterampilan sosial maka anak akan mampu menerima norma-norma sosial yang berlaku dalam masyarakat, serta dapat bersikap dalam perilaku yang dianggap normal, diterima dan dalam situasi sosial tertentu.
Rogers and Ross dalam Jo Ann Brewer (2007 : 23) ikut menjelaskan bahwa yang dimaksud dengan keterampilan sosial adalah: "Ability to asses what is happening in a social situation; skill to perceive and correctly interpret the actions and needs of the children on the group at play; ability to imagine possible courses of action and select the most appropriate one". Pendapat ini menjelaskan bahwa keterampilan sosial merupakan kemampuan untuk menilai apa yang terjadi dalam situasi sosial, juga keterampilan untuk memahami yang benar serta yang patut dilakukan kepada orang lain.

Menurut pendapat Cummimgs dan Haggerty dalam Claudia Eliason (2008 : 132) mengatakan bahwa : "Children learn social skills when teachers give these skill the same attention and focus that they give to academic subjects". Hal ini menjelaskan bahwa anak-anak atau peserta didik belajar tentang keterampilan sosial ketika seorang guru memberikan contoh dan teladan melalui pembelajaran maupun perilaku dan sikap sehari-hari. 
Perkembangan keterampilan sosial anak sangat dipengaruhi oleh kondisi anak dan lingkungan sosialnya, baik orang tua, teman sebaya, dan masyarakat sekitar. Hal ini sejalan dengan pendapat Pamela May (2011 : 42 ) mengatakan bahwa : For young children to develop good social skills, or what is sometimes known as prosocial behavior, they need to feel good abaout themselves and to feel a certain amount of autonomy and independence. Hal ini menjelaskan bahwa anak belajar mengembangkan keterampilan sosial dengan baik, saat mereka merasa nyaman dan merasa bebas mengeksplorasi perasaannya secara bebas. Melalui kebebasan dalam bergaul anak dengan mudah akan melakukan interaksi. Namun kebebasan tersebut tetap harus bertanggung jawab.

Pada saat memasuki usia sekolah TK anak mulai memiliki kesanggupan menyesuaikan diri sendiri (egosentris) kepada sikap yang kooperatif (bekerja sama) atau sosiosentris (mau memperhatikan kepentingan orang lain. Berkat perkembangan keterampilan sosialnya anak dapat menyesuaikan diri dengan kelompok dan teman sebayanya maupun dengan lingkungan masyarakat sekitarnya. Dalam proses belajar di sekolah, kematangan perkembangan keterampilan sosial ini dapat dimanfaatkan atau dimaknai dengan memberikan tugas-tugas kelompok, baik yang membutuhkan tenaga fisik maupun tugas yang membutuhkan pikiran. Hal ini dilakukan agar anak belajar tentang sikap dan kebiasaan dalam bekerja sama, saling menghormati dan bertanggung jawab.

Berdasarkan berbagai paparan di atas dapat peniliti simpulkan bahwa keterampilan sosial adalah kecakapan atau kemampuan dalam membina dan menjalin hubungan dengan orang lain dalam hal berkomunikasi dan berinteraksi, serta dapat menciptakan hubungan yang baik melalui sikap dan perilaku. Aspek-aspek keterampilan sosial yang perlu dikembangkan pada anak sejak usia dini, diantaranya ; kerjasama, komunikasi, empati, 
memahami aturan, dan bertanggung jawab. Pada akhirnya dengan melatih dan mengembangkan keterampilan sosial pada anak sejak berusia dini, diharapkan anak akan mampu bertahan dalam kondisi apapun di lingkungan tempat ia berada.

\section{Bermain Menggunakan Nyanyian}

Bermain bagi anak usia taman kanak-kanak merupakan kegiatan yang bermanfaat dalam pengembangan berbagai aspek potensi yang dimilikinya. Bermain dapat digunakan sebagai media untuk meningkatkan keterampilan sosial dan kemampuan tertentu pada anak. Istilah bermain diartikan sebagai suatu kegiatan yang dilakukan dengan mempergunakan atau tanpa mempergunakan alat yang menghasilkan pengertian, memberikan informasi, memberikan kesenangan, dan dapat mengembangkan imajinasi anak.

Menurut Lev Vygotsky dalam Sue Dockett \& Marilyn Fleer ( 2003 : 63 ) mengatakan bahwa : "Plays is always a social symbolic experience. Even when children play alone, they draw on themes and experiences and roles that are social is origin and they use social symbols to achieve this. Hal ini menjelaskan bahwa bermain selalu memberi pengalaman tersendiri pada diri anak, bahkan ketika anak bermain sendiripun ia akan merasakan bahwa seolah-olah ia sedang berada bersama orang lain.

Pendapat lain menurut Mulyasa (2011 : 166) mengatakan bahwa bermain bagi anak usia dini dapat mempelajari dan belajar banyak hal, seperti mengenal aturan, bersosialisasi, menempatkan diri, menata emosi, toleransi, kerja sama, dan menjunjung tinggi sportivitas. Di samping itu, aktivitas bermain pada anak juga dapat mengembangkan kecerdasan mental, spiritual, bahasa, dan keterampilan motorik, keterampilan sosial dan berbagai keterampilan hidup lainnya.. Bermain bagi anak usia dini merupakan pembelajaran yang sangat penting.

Adapun menurut Montessori dalam Suyadi ( 2013 : 34 ) menjelaskan bahwa : "For the child play is an enjoyable, voluntary, purposeful, and spontaneously choosen activity. It is often creative 
as well involving problem solving, learning, new social skill, newlanguage and new physical skills". Hal ini menjelaskan bahwa bagi anak, permainan adalah sesuatu yang meneyenangkan, suka rela, penuh arti dan aktivitas spontan. Permainan sering dianggap kreatif, yang menyertakan pemecahan masalah, belajar tentang keterampilan sosial, bahasa dan keterampilan fisik.

Menurut Jean Jacques Rousseau, dalam Mukhtar (2013 : 100) bermain adalah kodrat anak dan mereka memiliki kemampuan untuk memilih apa yang ingin mereka pelajari, anak bermain karena menginginkan kebebasan. Aktivitas bermain seraya belajar memberikan pengetahuan pada anak untuk melatih dan belajar berbagai macam keahlian dan konsep yang berbeda. Menurut Justine Howard (2011 : 10) mengatakan bahwa: "in play, children have the opportunity to learn about themselves and others. They become aware of the impact of their behaviour and develop skills in conflict resolution, negotiation, trust and acceptance". Hal ini berarti dalam kegiatan bermain, anak-anak memiliki kesempatan untuk belajar tentang diri sendiri dan orang lain. Mereka menjadi sadar akan dampak dari perilaku mereka dan mengembangkan keterampilan dalam resolusi konflik, negosiasi, kepercayaan dan penerimaan.

Salah satu aktivitas yang menyenangkan saat bermain bagi anak adalah bernyanyi. Selain sebagai kegiatan yang dapat menghadirkan rasa senang, bernyanyi juga bisa mengembangkan imaginasi anak. Kemampuan anak dalam bernyanyi pada usia dini didasarkan pada pengalamannya saat mendengar musik atau mendengar nyanyian orang tua dan orang-orang disekitarnya. Menurut Yusep (2012 : 13) aktivitas bernyanyi pada anak dibedakan menjadi dua bagian, diantaranya adalah sebagai berikut : (1) bernyanyi pasif, artinya anak hanya mendengarkan nyanyian dan musik serta menikmatinya, tanpa terlibat secara langsung dalam kegiatan bernyanyi, (2) bernyanyi aktif, yaitu anak melakukan secara 
langsung kegiatan bernyanyi, baik melakukan sendiri, mengikuti atau bersama-sama.

\section{Aktivitas musik bisa} digolongkan dalam bermain aktif bila anak melakukan kegiatan musik misalnya bernyanyi. Kegiatan bermain dengan menggunakan nyanyian merupakan kegiatan yang paling banyak dilakukan karena tidak menuntut keahlian memainkan alat musik. Manfaat yang dapat diperoleh adalah untuk ekspresi diri sosialisasi dan memupuk rasa percaya diri pada anak. Menurut Mayesky ( 2013 : 399 ) menjelaskan bahwa: "Music is a common and enjoyable occurence in a young child's life. One of the main goals of musical activities for young children is to maintain this natural appreciation of musical experiences". Hal ini menjelaskan bahwa musik adalah kegiatan yang sudah umum dan menyenangkan dalam kehidupan seorang anak. Salah satu tujuan utama dari kegiatan bermusik untuk anak-anak adalah untuk mempertahankan apresiasi alam ini melalui pengalaman musikal.
Menurut Brewer (2007 : 428 ) yang mengatakan : “ All children deserve a rich musical environtment in which to learn, to sing, to play, to move, and listen". Hal ini berarti bermusik bagi semua anak juga berguna untuk membantu mereka dalam mendapatkan pengetahuan, belajar, bermain, bergerak, mendengar dan memahami isi dari pengalaman mereka. Karakteristik bermusik pada anak usia dini haruslah nyanyian yang ceria, mudah di cerna dan akrab dengan lingkungan anak. Menurut Yusep (2012 : 10) mengatakan bahwa musik, gerak dan lagu adalah sarana belajar yang menyenangkan bagi anak usia dini. Hal ini tentu akan sangat bermanfaat bagi anak secara jasmani dan rohani. Selain menyenangkan, gerak dan lagu juga dapat menstimulasi perkembangan anak.

Rae Pica (2013 : 9) ikut menjelaskan bahwa untuk membangun dan mengembangkan berbagai aspek dan keterampilan hidup secara bertahap pada anak usia dini, guru bisa menerapkan berbagai metode dan media bermain yang 
cocok untuk dalam pembelajarannya. Penggunaan nyanyian saat bermain juga sangat besar pengaruhnya terhadap perkembangan hidup anak. Menurut Isenberg \& Jolongo (2000) dalam Rae Pica mengatakan bahwa : "to same early childhood professionals, the term brings to mind social play, or the ability of children to interact which each other". Hal ini menjelaskan bahwa bagi beberapa anak agar tampak profesional, mereka harus sering berinteraksi dan berhubungan dengan banyak orang dalam keberagaman sosialitas, hal ini dimaksudkan agar anak dapat berinteraksi dengan baik kepada semua orang.

Berdasarkan berbagai uraian di atas maka dapat peneliti simpulkan bahwa melalui bermain dan bernyanyi anak dapat megembangkan aspek perkembangannya. Musik merupakan sesuatu yang asyik untuk didengar. Musik juga merupakan kebutuhan pokok setiap manusia, karena musik dapat membuat orang merasa senang, gembira dan nyaman. Dengan bernyanyi anak merasa senang dan bila nyanyian digabung dalam permainan maka diharapkan anak akan mampu mengembangkan bakat dan potensi yang ada dalam dirinya.

\section{Metode Penelitian}

Penelitian ini menggunakan metode penelitian tindakan (action research) yang bersifat partisipasif dan kolaboratif. Model penelitian tindakan yang digunakan dalam penelitian ini yaitu menurut prosedur yang dikemukakan oleh Stephan Kemmis dan Mc Taggart. Penelitian tindakan melalui kegiatan pembelajaran dapat dilakukan dengan tahapan yang terdiri dari: (1). Perencanaan, (2) tindakan, pengamatan hasil, (4) Refleksi. Pada tahap refleksi, dapat dilihat peningkatan yang terjadi akibat dari intervensi tindakan yang diberikan dan memungkinkan untuk melakukan perencanaan tindakan lanjutan untuk siklus berikutnya.

Peneliti merencanakan tindakan dengan dua siklus dan setiap siklus dilaksanakan sembilan kali pertemuan. Pendekatan kualitatif dilakukan untuk 
menjelaskan rangkaian peristiwa yang terjadi selama kegiatan penelitian sehingga mendapatkan gambaran, informasi dan penjelasan yang lengkap tentang masalah yang sedang diteliti. Sedangkan pendekatan kuantitatif digunakan untuk menganalisa data hasil proses belajar atau untuk membandingkan keterampilan sosial anak sebelum dan sesudah dilaksanakan tindakan.

Peningkatan keterampilan sosial anak usia $5-6$ tahun di kelompok B5 TK Bintang Kecil Abepura, dengan jumlah anak 18 orang. Salah satu metode pembelajaran yang dilakukan yaitu melalui bermain dengan menggunakan nyanyian. Kegiatan bermain dengan nyanyian ini dilaksanakan oleh kolaborator, mengacu pada rencana yang telah diprogramkan. Dalam hal ini antara peneliti dan kolaborator saling bekerja sama sehingga rencana yang telah dibuat dapat terlaksana dengan baik. Pada saat kolaborator melakukan kegiatan bermain maka tugas yang harus dilakukan peneliti adalah melakukan pengamatan terhadap perilaku yang dilakukan anak. Pengamatan perilaku anak tidak hanya pada saat anak bermaian, akan tetapi pengamatan ini berlangsung selama anak berada di sekolah.

Teknik analisis data yang digunakan yaitu menggunakan analisis data kualitatif dan kuantitatif. Analisis data kualitatif menggunakan analisis data Miles dan Huberman sedangkan analisis data kuantitatif menggunakan perhitungan sebesar presentase peningkatan keterampilan sosial anak setelah dilakukan melalui bermain dengan nyanyian. Seperti dalam rumus sebagai berikut :

$$
\mathrm{S}=\frac{\mathrm{R}}{\mathrm{N}} \times 100
$$

Keterangan:

$\mathrm{S}=$ Nilai yang diharapkan (dicari)

$\mathrm{R}=$ Jumlah skor dari item atau soal yang dijawab benar $\mathrm{N}=$ Skor maksimun dari tes tersebut. Intrumen pengumpulan data yang digunakan yaitu lembar observasi, catatan lapangan, catatan wawancara, dokumentasi, dan instrument pemantau tindakan. Untuk uji validitas instrument menunjukan seberapa jauh instrument dapat 
mengukur apa yang hendak diukur terhadap konsep yang diukur, sehingga betul-betul mengukur apa yang seharusnya diukur. Dari pendapat di atas maka validasi instrument dilakukan melalui penilaian oleh ahli (expert judgment). Adapun jumlah tenaga ahli yang akan melakukan validasi terhadap instrument dalam penelitian ini adalah sebanyak tiga orang pakar. Tenaga ahli tersebut sesuai dengan lingkup yang diteliti dalam penelitian dan umunya mereka yang telah bergelar doktor sesuai kajian penelitian yang akan diteliti.

\section{Hasil Dan Pembahasan}

Assesmen awal pada peningkatan keterampilan sosial dengan kegiatan bermain dengan nyanyian rata-rata kelas 49,30\% ini berarti menunjukan bahwa masih banyak anak kelompok B5 TK YPPK Bintang Kecil yang belum ada kerjasama, komunikasi, empati, memahami aturan dan tanggung jawab atau dikatakan bahwa keterampilan sosial anak masih rendah. Hasil Assesmen awal keterampilan sosial anak dapat dilihat pada grafik di bawah ini :

Grafik 1. Hasil Asessment Awal Tentang Keterampilan Sosial Anak Kelompok B5 TK YPPK Bintang Kecil Abepura

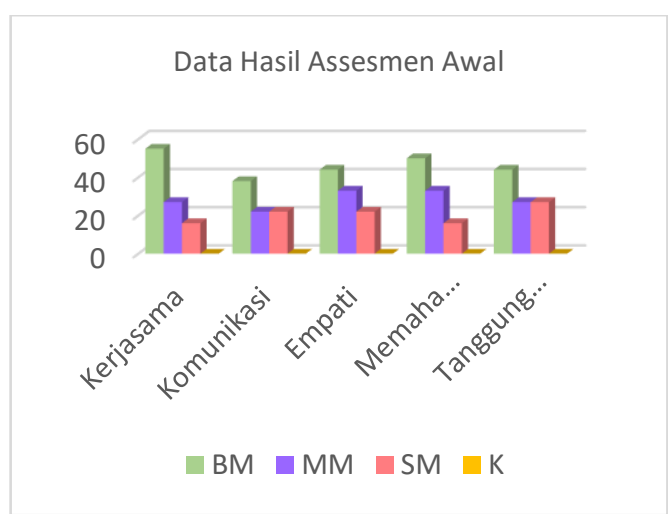

Berdasarkan grafik di atas menunjukan masih rendahnya keterampilan sosial anak, terlihat dari pada aspek kerjasama, komunikasi, empati, memahami aturan, dan tanggung jawab, pada taraf penilaian belum muncul, dan mulai muncul sedangkan sering muncul dan konsisten masih sedikit anak pada tahap penilaian ini.

Setelah diberikan tindakan pada siklus I maka peningkatan keterampilan sosial anak kelompok B5 TK YPPK Bintang Kecil meningkat sebesar $71,18 \%$. Hal ini menunjukan rata-rata kenaikan peningkatan disiplin pada anak mencapai 28,169\%. Dari 18 orang 
anak ada 5 orang anak yang mendapatkan skor yang terendah pada siklus I yaitu $\mathrm{DN}=65,17 \%$, GL $=64,28 \%, \mathrm{JR}=66,96 \%, \mathrm{CL}=$ $67,85 \%$, PT $=66,07 \%$. Berhubung ke lima anak tersebut belum mencapai target pencapaian tindakan maka proses tindakan dilanjutkan pada siklus ke II. Pada siklus ini telah terlihat hasil yang cukup baik, dari ke 18 anak yang diberikan tindakan, maka terlihat peningkatan keterampilan sosialnya. Ke lima anak yang belum mencapai target keberhasilan pun telah meningkat dengan baik. Data peningkatan pada siklus II menunjukan bahwa terjadi peningkatan yang signifikan yaitu sebesar $84,42 \%$, hasil ini dapat dilihat pada tabel di bawah ini :

Tabel 1. Peningkatan Keterampilan Sosial Anak dari Pra intervensi, Siklus I sampai Siklus II

\begin{tabular}{|c|c|c|c|}
\hline NAMA & $\begin{array}{c}\text { PRA } \\
\text { SIKLUS }\end{array}$ & $\begin{array}{c}\text { SIKLUS } \\
\text { I }\end{array}$ & $\begin{array}{c}\text { SIKLUS } \\
\text { II }\end{array}$ \\
\hline ART & $24,11 \%$ & $8,03 \%$ & $32,14 \%$ \\
\hline JRO & $25 \%$ & $8,04 \%$ & $33,04 \%$ \\
\hline AXL & $30,77 \%$ & $10.71 \%$ & $41,07 \%$ \\
\hline ELL & $23,21 \%$ & $12,05 \%$ & $35,71 \%$ \\
\hline DNL & $13,39 \%$ & $17,86 \%$ & $31,25 \%$ \\
\hline KZI & $25 \%$ & $7,14 \%$ & $32,14 \%$ \\
\hline GIL & $15,18 \%$ & $18,75 \%$ & $33,93 \%$ \\
\hline
\end{tabular}

\begin{tabular}{|c|c|c|c|}
\hline JMS & $16,07 \%$ & $16,96 \%$ & $33,03 \%$ \\
\hline CAL & $16,07 \%$ & $16,97 \%$ & $33,04 \%$ \\
\hline GLN & $20,53 \%$ & $14,29 \%$ & $34,82 \%$ \\
\hline CHL & $21,43 \%$ & $15,17 \%$ & $36,6 \%$ \\
\hline ALF & $25 \%$ & $14,29 \%$ & $39,29 \%$ \\
\hline RSC & $20,54 \%$ & $12,5 \%$ & $33,04 \%$ \\
\hline PET & $23.22 \%$ & $16,96 \%$ & $40.18 \%$ \\
\hline RYN & $23,21 \%$ & $14,29 \%$ & $37,5 \%$ \\
\hline OKA & $23,21 \%$ & $11,61 \%$ & $34,82 \%$ \\
\hline ABG & $26,79 \%$ & $12,5 \%$ & $39,29 \%$ \\
\hline VYA & $22.32 \%$ & $8,93 \%$ & $31,25 \%$ \\
\hline $\begin{array}{c}\text { Rata- } \\
\text { rata } \\
\text { kelas }\end{array}$ & $\mathbf{2 1 , 9 3 \%}$ & $\mathbf{1 3 , 1 9 \%}$ & $\mathbf{3 5 , 1 2} \%$ \\
\hline
\end{tabular}

Berdasarkan data hasil peningkatan keterampilan sosial anak kelompok B5 TK YPPK Bintang Kecil yang berjumlah 18 orang anak dapat dilihat pra intervensi dengan rata-rata hasil peningkatan disiplin sebesar 49,30\% mengalami kenaikan pada siklus I sebesar 21,93\% dengan rata-rata hasil peningkatan keterampilan sosial mencapai $71,18 \%$. Kemudian dari siklus I ke siklus II kenaikan peningkatan keterampilan sosial mencapai $35,12 \%$ dengan rata-rata hasil peningkatan keterampilan sosial mencapai $84,42 \%$. Data hasil analisis kualitatif dan kuantitatif di atas dapat di lihat pada grafik di bawah ini : 
Grafik 2. Data hasil Peningkatan Keterampilan Sosial Anak Kelompok B5 TK YPPK Bintang Kecil Abepura pada Siklus I dan Siklus II

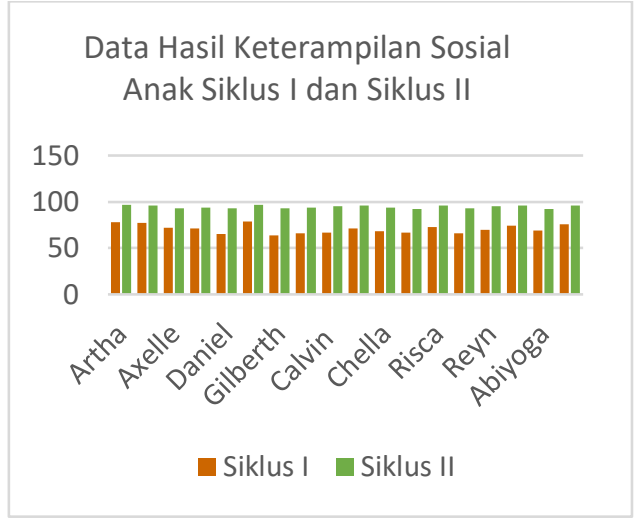

Berdasarkan grafik di atas dapat dijelaskan bahwa melalui kegiatan bermain menggunkana nyanyian dapat meningkatkan keerampilan sosial anak. Hal ini terlihat pada grafik yang berwarna hijau yang menandakan tingkat keberhasilan tindakan pada siklus II telah berhasil mencapai nilai ketuntasan sebersar $70-90 \%$.

\section{Simpulan}

Keterampilan sosial anak di kelompok B5 TK Bintang Kecil Abepura mengalami peningkatan setelah diberikan stimulus dengan menggunakan metode bermain dengan menggunakan nyanyian diantaranya

(bermain ekspresi, bermain saputangan, bermain ular naga, bermain domikado, bermain pikirpikir, dan bermain cari teman). Keterampilan sosial anak TK YPPK Bintang Kecil sebelum dilakukan bermain dengan menggunakan nyanyian masih sangat rendah dengan rata-rata dari semua aspek adalah $53,24 \%$ penilaian keterampilan sosial mereka pada kategori belum muncul. Dengan demikian masih perlu dilakukan upaya peningkatan keterampilan sosial anak yaitu antara lain dengan melakukan kegiatan bermain dengan nyanyian. Peningkatan dimulai pada pra intervensi ke siklus I meningkat menjadi $28,178 \%$ dengan rata-rata peningkatan disiplin sebesar $71,18 \%$.

Dilanjutkan pada siklus II dengan kenaikan mencapai 9,978\% dengan rata-rata peningkatan sebesar $84,42 \%$. Berdasarkan hasil tersebut menunjukan bahwa penelitian ini sudah berhasil, menyatakan bahwa keterampilan sosial anak usia 5-6 tahun kelompok B5 TK YPPK Bintang Kecil telah meningkat melalui kegiatan bermain dengan nyanyian, oleh karena itu berdasarkan kesepakatan antara 
peneliti dan kolaborator maka kriteria keberhasilan adalah sebesar $71 \%$ - 90\% masing-masing anak untuk semua aspek.

Tindakan yang dirancang untuk keterampilan sosial anak yaitu melalu kegiatan bermain dengan menggunakan nyanyian. Tahapan bermain dengan nyanyian dilakukan pada siklus I dengan melaksanakan sembilan kali pertemuan. Berdasarkan hasil akhir setelah siklus I, maka keterampilan sosial anak mengalami peningkatan, akan tetapi ada lima orang anak yang belum memenuhi kriteria yang disepakati bersama peneliti dan kolaborator sehingga harus dilanjutkan pada siklus II. Pada siklus II, peneliti menambahkan satu permainan sehingga pada siklus yang kedua menjadi enam permainan. Peneliti dan kolaborator merancang melaksanakan sembilan kali pertemuan seperti pada siklus I.

Adapaun langkah-langkah dalam bermain dengan nyanyian yaitu dengan menyediakan tempat untuk bermain baik di dalam kelas maupun di luar kelas, menyiapkan alat atau media untuk bermai, membagi anak dalam kelompok, guru menjelaskan aturan atau langkah-langkah dalam setiap permainan.

\section{Saran}

Bagi guru, kegiatan bermain dengan menggunakan nyanyian dapat dilaksanakan setiap hari di lembaga sebagai variasi pembelajaran yang dapat menarik perhatian anak untuk lebih tertarik mengikuti pembelajaran. Guru sebaiknya selalu memberikan penguatan, reward, dan juga feedback terhadap apa yang diungkapkan oleh anak, sehingga anak merasa dihargai dengan keberaniannya.

Bagi kepala Sekolah TK, dapat memasukkan berbagai kegiatan bermain dengan nyanyian dalam program yang digunakan sekolah, agar proses pembelajaran lebih menarik dan bervariasi.

Bagi orang tua, hendaknya dapat memberikan kesempatan bagi anak untuk membangun hubungan sosial dengan orang lain dan mendukung kegiatan pembelajaran yang bertujuan untuk mengoptimalkan 
semua aspek perkembangan anak dan potensi yang di miliki oleh anak.

Bagi Dinas Pendidikan Kota Jayapura, agar dapat membuat kebijakan pendidikan yang berkenaan dengan penggunaan alat dan media pembelajaran yang sesuai dengan tahapan perkembagan anak, secara khusus untuk mengembangkan keterampilan sosial anak usia TK.

\section{Daftar Pustaka}

Brewer Ann Jo. Early Childhood Educatin, Preschool Through Primary Grades, Sixth Edition, United State : Pearson, 2007.

Cynthia, G.Simpson \& Sharon A. Lynch. Social Skills.Laying the Foundation for Success, volume 38, Number 2. Dimensions of early Childhood : Spring Summer. 2010.

Dawn Alderson \& Justine Howard. Play In Early Childhood,From Birth to Six Years. London : Routledge. 2011.

Loa Jenkins, \& Claudia Eliason. A Pratical Guide To Early Childhood Curriculum New Jersey : Pearson Education. 2008.

Marilyn Fleer \& Sue Dockett. Play and Pedagogy in Early Childhood. Bending The
Rules. Sydney : Includes Index. 2003.

Mayesky Mary. Creative Activities for Young Children. United States : Premedia Global. 2012.

Milburn,J.F. \& Cartledge,G. Teaching social skills to children \& youth: Innovative approaches (3rd ed). Massachussetts : Allyn and Bacon.1995

Mukhtar latif, dkk. Pendidikan Anak Usia Dini. Teori Dan Aplikasinya. Jakarta : Kencana Prenada. 2013.

Mulyasa. Manajemen Paud. Bandung: Remaja Rosda Karya. 2012.

Nurjatmika Yusep. Ragam Aktivitas Harian untuk Play group. Jakarta : Diva Press, 2012.

Patrick, J.Nancy. Life Social Skills For Teenagers And Adults with Asperger Syndrome. London : Jessica Kingsley Publisher. 2008.

Pamela May. Child Development In Practice. United State : Cataloguing in Publication Data. 2011.

Pica Rae. Experiences In Movement \& Music. United State : Wadsworth, Cengage Learning. 2013.

Ulfah Maulidya \& Suyadi. Konsep Dasar Paud. Bandung : Rosdakarya.2013. 
